ppi $201502 Z U 4645$

Esta publicación científica en formato digital es continuidad de la revista impresa ISSN-Versión Impresa 0798-1406 / ISSN-Versión on line 2542-3185Depósito legal pp $197402 Z$ U34

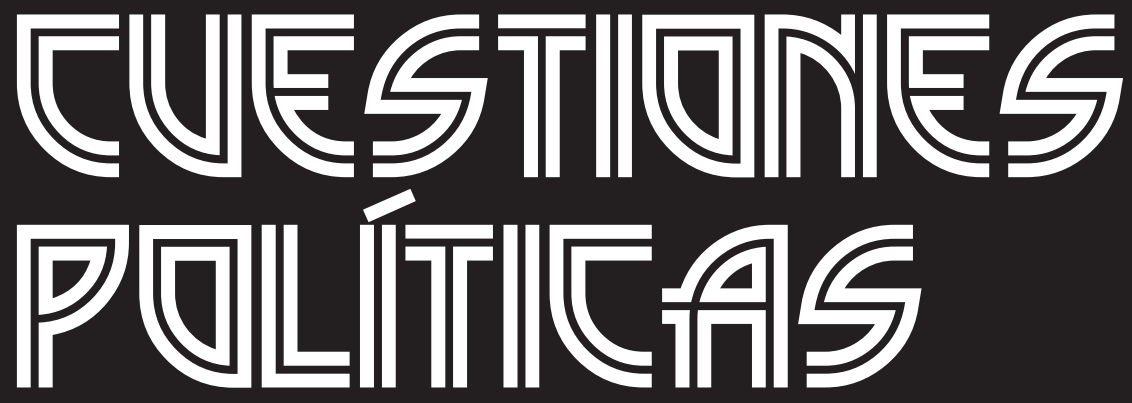

Instituto de Estudios Políticos y Derecho Público "Dr. Humberto J. La Roche" de la Facultad de Ciencias Jurídicas y Políticas de la Universidad del Zulia Maracaibo, Venezuela
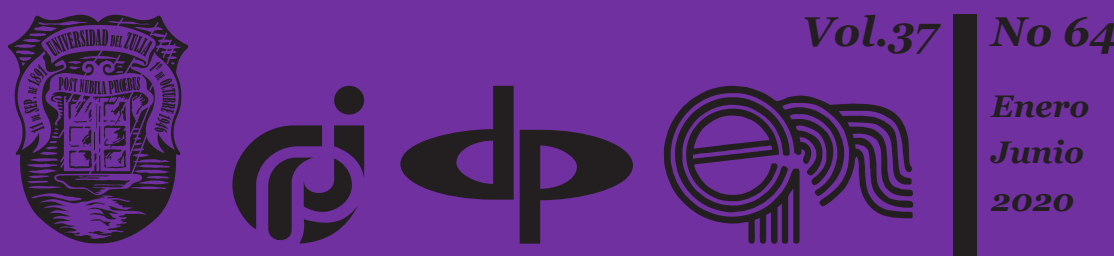


\title{
Ensuring Human Rights in Ukraine: Problematic Issues and Ways of their Solution in the Social and Legal Sphere
}

\author{
Yevhen Leheza * \\ Tatiana Filipenko ** \\ Olha Sokolenko *** \\ Valerii Darahan **** \\ Oleksii Kucherenko ${ }^{* * * * *}$
}

\begin{abstract}
The article discusses some complex factors influencing the process of realization of human rights in Ukraine, highlights the unified approach to the classification of legal norms that exercise human rights and freedoms, as well as problems and development prospects. Now the real protection of human rights is one of the most acute problems of the Ukrainian reality. It serves as one of the most important tasks, not only for the functioning but also for the existence of the Ukrainian state. Therefore, it should be borne in mind that guaranteeing respect for human rights in Ukraine is only possible through effective reform of the power system and compliance with an integrated approach to guarantee human rights, both by the State and by society. civil. It is concluded that guaranteeing the general enjoyment and enjoyment of human rights is a matter of co-responsibilities, which is why it is also negatively affected by the rigid opposition of the political forces, which undermines the stability of society, the stability of the constitutional order, while increasing the low level of legal culture of officials and citizens.
\end{abstract}

Keywords: human rights in Ukraine; legal guarantees; social and legal field; human rights issues; democracy in Ukraine.

Professor, Doctor of Science in law, Professor at the Department of Administrative and Customs Law, University of Customs and Finance, Ukraine. E-mail: yevhenleheza@gmail.com.

** Professor, Doctor of Science in law, Professor of Department of Law and Public Administration, Mariupol State University, Ukraine. Email: tatkafili@gmail.com.

*** Professor, Doctor of Science in law, Dean of the Faculty of Law, Oles Honchar Dnipro National University, Ukraine. Email: sokolenko2003dnu@ukr.net.

****Assistant professor, Doctor of Science in law, Head of the Department of Criminal Procedure, Dnipropetrovsk State University of Internal Affairs, Ukraine. Email: velcomo7@gmail.com.

***** PhD in law, Leading specialist of human resources department, Dnipropetrovsk State University of Internal Affairs, Ukraine. Email: OleksiiKucherenko@gmail.com.

Recibido: 02/03/2020

Aceptado: 04/04/2020. 


\section{Garantías de los derechos humanos en Ucrania: cuestiones problemáticas y formas de su solución en el ámbito social y jurídico}

\section{Resumen}

El artículo analiza algunos factores complejos que influyen en el proceso de realización de los derechos humanos en Ucrania, destaca el enfoque unificado para la clasificación de las normas legales que ejercen los derechos humanos y las libertades, así como los problemas y las perspectivas de desarrollo. Ahora la protección real de los derechos humanos es uno de los problemas más agudos de la realidad ucraniana. Sirve como una de las tareas más importantes, no solo para el funcionamiento sino también para la existencia del estado ucraniano. Por lo tanto, debe tenerse en cuenta que garantizar el respeto de los derechos humanos en Ucrania solo es posible mediante una reforma efectiva del sistema de poder y el cumplimiento de un enfoque integrado para garantizar los derechos humanos, tanto por el Estado como por la sociedad civil. Se concluye que, garantizar el goce y disfrute generalizado de los derechos humanos es una cuestión de corresponsabilidades, por lo que también se ve afectado negativamente por la rígida oposición de las fuerzas políticas, que socava la estabilidad de la sociedad, la estabilidad del orden constitucional, al tiempo que incrementa el bajo nivel de cultura legal de los funcionarios y ciudadanos.

Palabras clave: derechos humanos en Ucrania; garantías legales; ámbito social y jurídico; problemáticas de los derechos humanos; democracia en Ucrania.

\section{Introduction}

The problem of ensuring human rights at the end of XX - beginning of XXI century has become one of the most urgent problems of humanity and has complex domestic and international aspects of manifestation. This problem is closely connected with the insufficient level of observance of human rights and freedoms enshrined in the Constitution of Ukraine by the State, which is manifested both in certain difficulties in the implementation of some of them (first of all, it concerns socioeconomic rights) and in the insufficient level of their protection from offenses.

The constitutional and legal status of the person should be understood as a system of relations between the individual and the State enshrined in the 
Yevhen Leheza, Tatiana Filipenko, Olha Sokolenko, Valerii Darahan y Oleksii Kucherenko Ensuring Human Rights in Ukraine: Problematic Issues and Ways of their Solution in the Social

Constitution, which includes such constituent elements as constitutional rights, freedoms and obligations, basic principles of the constitutional and legal status of the person enshrined in the Constitution, citizenship.

The adoption of the Constitution of Ukraine was an important step in the legislative regulation of the fundamental rights and freedoms of citizens by the Parliament of Ukraine. The current constitutional legislation of Ukraine in terms of protection of the rights and freedoms of citizens complies with international legal standards of human rights, the Universal Declaration of Human Rights of December 10, 1948, the International Covenant on Civil and Political Rights of December 19, 1966, the International Covenant on Economic, Cultural and Social Rights of December 19, 1966.

Last year, public organizations recorded almost 300 violations of freedom of speech, of which about 100 consisted in attacks on journalists. The appeal was open for new signers, and within several weeks dozens of people and professional journalists joined it every day (Ukraine Human Rights Monitoring in January 2018 - April 2019, 2019).

\section{Literature review}

Scientists were engaged in research of problems of human rights in Ukraine, however the unified approach concerning system of human rights in Ukraine has not implemented. The relevance of this Article is also due to the fact that the results of research of human rights in Ukraine are known in science, which, of course, is important, but does not reflect the full picture of the complex nature. The rights of citizens, are the components of a unified mechanism for the protection of the rights of citizens, which is intended to ensure the restoration of the right, elimination of obstacles to its implementation, prevention of violations and compensation for the moral and material damage. In particular, the protection of subjective rights, freedoms and interests protected by law is carried out in the manner prescribed by law, that is, through the use of the appropriate form, means and methods of protection (Sokolenko, 2019).

Thus, the purpose of this article is to define human rights as a specific global problem, the solution of which depends on each State, on the quality of constitutional regulation and constitutional control of public relations. This problem occupies an important place in the "catalogue" of human problems that must be solved. 


\section{Materials and methods}

The basis of the study is philosophical methods: dialectical (the basic principles of which are objectivity, comprehensiveness, concreteness and completeness of knowledge, division of the united and knowledge of its contradictory sides etc.), logical (the main methods of which are analysis and synthesis, induction and deduction, analogy, ascent from concrete to abstract and from abstract to concrete), etc.

Among the scientific methods of cognition are used methods of system analysis (structural, functional, factor, genetic), target, typological, model. With regard to the knowledge of the realization of the human right to protect the law, the method of institutional analysis allows us to justify the contours of the real field of the implementation of the human right to protect the law as a single integrated legal institution, which is very valuable for identifying the laws of its functioning and improvement; classify the funds it contains into organizational and legal ones; to examine each organizational or legal means in terms of its adequacy to the meaning and purpose of the human right to protect the law, as well as its functional orientation to achieve its goal - to eliminate the threat to human rights security or restore it.

\section{Results}

The assertion of human rights and freedoms is their recognition by the State, which in the context of implementation can be carried out by various means, through appropriate actions of the State, its bodies and officials, for example, by pronouncing in declarations, statements, enshrining human rights in the Constitution, other laws, participation in the preparation and adoption of international human rights instruments by acceding to relevant international treaties and ratifying them (Alekseev, 1999). Ensuring human rights and freedoms is the creation of appropriate conditions for the exercise of human rights and freedoms, which includes the following three teleological dominants (purposeful directions) of State activity: 1) promoting the realization of human rights and freedoms (through a positive impact on the formation of their social guarantees); 2) protection of human rights and freedoms (by taking measures, in particular, legal ones, to prevent offenses); 3) protection of human rights and freedoms (in case of violation by any entity) (Bukanov et al, 2019; Borychenko et al, 2019; Bodnar et al, 2019).

The rights and freedoms of the human and the citizen, which are enshrined in the current Constitution of Ukraine, are not exhaustive, that is, in the future the system of rights and freedoms can be expanded 
Yevhen Leheza, Tatiana Fïlipenko, Olha Sokolenko, Valerii Darahan y Oleksii Kucherenko Ensuring Human Rights in Ukraine: Problematic Issues and Ways of their Solution in the Social 128 and Legal Sphere

and improved (The Legislation of Ukraine, 1996). It should be noted that the provisions of Article 3 of the Constitution of Ukraine are detailed in numerous articles of its Section II "Rights, freedoms and responsibilities of the human person and the citizen", the norms of which cannot be considered out of connection with the principle of recognition of the human, his rights and freedoms as the highest value, and, of course, they cannot be modified or supplemented in a manner contrary to this principle (The Legislation of Ukraine, 1996).

It should be noted that over the years of independence, our State has established a fairly satisfactory legislative framework for human and civil rights. First of all, as noted above, these rights have clear constitutional guarantees, and a number of legislative acts have been adopted that directly relate to this area. Among the legislative acts, which are the most important in this area, we should mention the following: Laws of Ukraine:

1. "On Citizenship in Ukraine" (The Legislation of Ukraine, 2001),

2. "On the Commissioner of the Verkhovna Rada for human rights" (The Legislation of Ukraine, 1998),

3. "On Immigration" (The Legislation of Ukraine, 2001),

4. "On Refugees" (The Legislation of Ukraine, 2001),

5. "On the rehabilitation of victims of political repression" (The Legislation of Ukraine, 1991),

6. "On Ukraine's accession to the UN Convention on the Status of Refugees and the Protocol on the Status of Refugees" (The Legislation of Ukraine, 2002) etc.

It should be noted that despite the fact that Ukraine has adopted democratic legislation in the field of human rights and freedoms, however, in the conditions of socioeconomic and political crisis, the decline of culture and morality, there are no effective mechanisms to protect these rights, which leads to their mass and systematic violations, and sometimes simply to the impossibility of their implementation. In order to build a democratic legal State in Ukraine, it is essential to combat legal nihilism, legal infantilism, and the phenomenon rebirth of legal consciousness, which manifests itself primarily in crime. All these forms of deformation of legal consciousness do not contribute to the establishment of a democratic legal culture oriented toward the value of constitutionalism (Alekseev, 1999). It is particularly important to eradicate organized crime, corruption, which significantly undermine citizens' belief in law and legislation, in the ability of the authorities to restore law and order in the country. The development of the shadow economy, lawlessness, legal arbitrariness are the essential factors of the development of legal nihilism, other forms of deformation of legal consciousness, which must be resolutely tackled on the basis of a well- 
defined state policy in the field of legal nurturing and legal education of the population, ordering in all spheres of public life.

The Constitution of Ukraine of 1996 enshrined civil (personal), political, social, economic, cultural, information, environmental rights and freedoms of the human and the citizen (Bukanov et al, 2019; Borychenko et al, 2019; Bodnar et al, 2019). This means that the Constitution of Ukraine has not only restricted the implementation of international legal acts and norms on human rights and freedoms, but has significantly expanded their composition and proclaimed, in particular, environmental and information rights. In addition, the Constitution substantially enriched the content of a significant part of the rights and strengthened the guarantees for their practical implementation. In particular, civil rights and freedoms of the human, which are recognized as fundamental, priority, include such rights and freedoms as the right to life (Article 27), the right to respect for his dignity (Article 28), right to freedom and personal inviolability (Article 29), the right to inviolability of domicile (Article 30, the secrecy of correspondence, telephone conversations, telegraph and other correspondence (Article 31, the right to non-interference with privacy and family life (Article 32) (The Legislation of Ukraine, 1996).

It is worth noting changes in the content of some of these rights and freedoms, including the rights and freedoms of personal inviolability, as well as the inviolability of domicile. Thus, Article 30 of the Constitution stipulates that "everyone shall be guaranteed the inviolability of his domicile. Intrusion into a person's domicile or other property, inspection or search thereof, shall not be permitted except when under a substantiated court decision. In urgent cases related to preservation of human life and property or to the direct pursuit of persons suspected of committing a crime, other procedures of entering a person's domicile or other property, inspecting or searching thereof, determined by law, shall be allowed". A systematic analysis of the relevant provisions of the Constitution of the USSR of 1978 and the current Constitution of Ukraine states that earlier this right concerned only domicile and did not apply to the property, that is, to other possessions of the person.

After the use of all domestic remedies, everyone has the right to apply for the protection of his rights and freedoms to the relevant international judicial authorities or the respective bodies of international organizations of which Ukraine is a member or party (Part 4 of Article 55 of the Constitution of Ukraine), (The Legislation of Ukraine, 1996).

The most important international legal act of a regional nature on human rights is the European Convention for the Protection of Human Rights and Fundamental Freedoms, which was adopted by the Council of Europe in Rome (Italy) on November 4, 1950 (Ukraine ratified the Convention on July 17, 1997 (On the ratification of the Convention for the Protection of 
Yevhen Leheza, Tatiana Filipenko, Olha Sokolenko, Valerii Darahan y Oleksii Kucherenko Ensuring Human Rights in Ukraine: Problematic Issues and Ways of their Solution in the Social

Human Rights and Fundamental Freedoms of 1950, 1997). It enshrines a set fundamental rights and freedoms of the human; the criminal procedure guarantees of their observance and implementation. In order to protect these rights and freedoms, the European Court of Human Rights has been established, whose jurisdiction extends to all these cases and whose decisions are binding on all States Parties to the Convention (Bukanov et al, 2019).

There are other international legal acts of a regional nature on human rights: the European Social Charter (1961), the European Convention for the Prevention of Torture and Inhuman or Degrading Treatment or Punishment (1987) (Loizidou, 1996; Hornsby, 1997).

Article 14 of the ICCPR further requires that "all persons shall be equal before the courts and tribunals" and in criminal trials "everyone shall be guaranteed the right to a fair and public hearing by a competent, independent and impartial tribunal established by law" (Human Rights Committee, General Comment 29, States of Emergency, 2001).

In addition to these basic rights, numerous international instruments and opinions further support the conclusion that basic procedural protections and due process rights are essential aspects of all human rights and should be protected (Loizidou, 1996; Hornsby, 1997).

Thus, constitutional rights and freedoms are certain opportunities established by the Ukrainian State, enshrined in its Constitution and other legislative acts, which allow every citizen to choose the appropriate type of their behavior, enjoy political, socioeconomic freedoms and social benefits in both personal and public interests. The constitutional obligations of a human and a citizen are a measure of proper behavior, which everyone must adhere to in order to ensure the normal functioning of other entities of civil society.

\section{Problematic issues of human rights in Ukraine and ways to solve them.}

Human rights have been, are, and will be, a reflection of the various processes occurring in society and nature, a reflection of the various interests, needs of people that arise in connection with these processes (Alekseev, 1999). And if until recently these needs concerned only the social, as broadly understood, side of people's lives, in recent decades they have also reflected the changes that occur due to the active influence of humans on the environment and on the nature of the human himself (Chermnykh and Zubko, 2016; Kvitka et al, 2019). 
In this regard, one of the directions of development of the catalogue of human rights can be connected with new revolutionary discoveries and achievements in practical medicine and biology, concerning the human nature as a biological being, namely organ transplantation and artificial insemination, solutions to the problems of euthanasia and cloning, the existence and use of genetically modified (transgenic) products etc. The invention and use of these discoveries, that invade the "Holy of Holies", the nature of human himself, raises a lot of questions, requires their critical reflection, the development of not only ethical but also legal criteria (Kostetska et al, 2020; Shmygol et al, 2020).

However, there are more than enough problems in the practical realization of personal rights. As Ukrainian scientist Yu. Shemshuchenko rightly points out "civil society becomes the basis of a democratic State only when its interests and the interests of the State are not opposed. A democratic State should remove the contradictions that arise between it and society. On the other hand, in the process of activity of political parties, public associations, mass media, the interests of civil society should be transformed into the interests of the State. In the case of conflicting interests of the State and society, the latter can turn into a destructive and destabilizing factor" (Shemshuchenko, 2017).

The implementation in practice of the constitutional principle of human rights as the highest social value implies sustainable economic development of the country (Kostetska et al, 2020; Shmygol et al, 2020), the presence of a clear state policy, which is focused on ensuring human rights and freedoms. World practice shows that the transition periods in the development of the State and statehood have always been unstable, characterized by inconsistency of public positions and ideological orientations. It is in these conditions that human rights violations in Ukraine have a systemic character and become signs of social catastrophe. The real reduction of wages, poverty coverage of the general population, the availability of pensions, which are lower than the established low-income level, the increasing commercialization of such vital constitutional rights as health and education, mass violations of the electoral law are vivid evidence of a total violation of total human rights (Chermnykh and Zubko, 2016; Kvitka et al, 2019).

Due to the fact that the State does not sufficiently ensure the realization of the rights and freedoms of citizens, their distrust of the State grows and their alienation from the authorities increases. This state of affairs is the cause of social apathy, which is caused by the indifference, irresponsibility of the relevant power structures, discrimination and discredit of democratic values in society, which sociologists have repeatedly noted in the process of analyzing the mood in society. The crisis state of the economy of Ukraine gives rise to social anemia of a very large part of the population, leading to sharp social differentiation. 
Yevhen Leheza, Tatiana Filipenko, Olha Sokolenko, Valerii Darahan y Oleksii Kucherenko Ensuring Human Rights in Ukraine: Problematic Issues and Ways of their Solution in the Social

The Verkhovna Rada of Ukraine, as the supreme legislative body of the State, provides protection of human and citizen's rights and freedoms through legislative activity, through the organization of special parliamentary hearings, which discuss perspective plans of legislative activity on profile problems, exercise control functions over the activities of law enforcement agencies and local state administrations in the field of human rights (Selejan-Gutan, 2011).

Pursuant to the requirements of the Law the Ministry of Justice of Ukraine on 2 July 2012, approved the Decree № 968/5 which established first 27 centers for the provision of secondary legal aid in the Autonomous Republic of Crimea, Kyiv and Sevastopol. During the first quarter of 2014, the abovementioned centers issued 16876 orders to the lawyers, including 5014 - to provide secondary legal aid to persons detained on suspicion of committing a crime; 10747 - for protection for intended purposes; 609 to provide secondary legal aid to persons who are under administrative detention; 506 - to participate in certain proceedings actions (SelejanGutan, 2011).

In our opinion, it is very important in the activity of the relevant ministries, state committees, and departments in the relevant sphere to intensify their work in informing the population about human rights, to work hard to ensure that the whole range of issues on the sphere of legislative support, practical implementation and protection of human and civil rights becomes more accessible for acquaintance and study to all members of society (Rabinovych, 2017). Only openness and publicity in this area can become a guarantee and effective factor of establishing in Ukraine a truly legal democratic state in which the rights and freedoms of citizens will be ensured (Rabinovych, 2017).

It is necessary to consider that nowadays in Ukraine the theory of recognition of human dignity, which is an integrative property of human nature and acts as one of the institutional sources of its fundamental rights. In this regard, the general theory of law formulates an anthropogenic interpretation of human dignity, the concept of which is defined as the selfworth of a human as a unique generic biosocial being (Rabinovych, 2017). In our opinion, these doctrinal positions in the near future will require appropriate legal and even constitutional regulation.

Firstly, material support of scientific research requiring considerable financial resources for the purposes of upgrade of machinery and equipment remains serious problem (Leheza et al, 2018).

Secondly, academic staff remains vulnerable. Level of salary of scientists remains the key problem of this category. So, the occupational prestige decreases sharply. Number of scientists who emigrated abroad decreased over the last years. However, this problem continues to be extremely relevant by this day (Leheza et al, 2018). 
The analysis of outflow of academic staff points to the fact that it is those scientists who emigrate abroad who may offer new knowledge that has no future perspectives for development or application in our country. In addition, the multinational mobility of academic staff becomes rather topical problem (Leheza et al, 2018).

Many domestic scientists go to foreign scientific centers (for the purposes of on-the-job training or occasional employment) according to international treaties on cooperation. Displacement of centers of scientific and technological activity occurs in doing so. The fact that most of scientists who stay in Ukraine deal with parallel kinds of activity (politics, entrepreneurship) also continues to be the topical issue (Leheza et al, 2018).

Given this, the process of the efficient scientific activity decreases, and sometimes becomes impossible. The national scientific potential does not fulfill the economic function under these circumstances, and it has long been emphasized by leading domestic scientists that the financial support problem may be solved according to situation, that state support of science is such that the science may fulfill exclusively social and cultural function (Martynyuk, 2014).

\section{Conclusion}

Thus, the Constitution of Ukraine is based on fundamentally new legal paradigms of foreign and domestic state policy of Ukraine aimed at affirming and protection of human and citizen's rights and freedoms. And this objectively requires a significant reorientation and modification of the entire national legal system.

It is emphasized that no less important problem is the shortcomings in the legislation itself, legal mechanisms for the implementation and protection of certain rights and freedoms are insufficiently developed; there are certain internal contradictions between them. For example, the current legislation of Ukraine on local self-government requires substantial improvement in order to ensure the priority of human and citizen's rights in the organization and operation of local self-government bodies; expansion of the range of entities of the right to participate in local self-government; development of powers of local self-government bodies in the financial and budgetary sphere, actual implementation of the principle of formation of the state budget from the "bottom", increase of the share of local budgets in the consolidated national budget in order to strengthen the material and financial base of local self-government. This will be facilitated by the consolidation and expansion of local self-government powers in the field of development and support of small and medium-sized enterprises, employment of local 
Yevhen Leheza, Tatiana Filipenko, Olha Sokolenko, Valerii Darahan y Oleksii Kucherenko Ensuring Human Rights in Ukraine: Problematic Issues and Ways of their Solution in the Social

residents. The issue of creating a system of administrative justice bodies for the legal protection of local self-government, human and citizen rights and freedoms in the current conditions of state formation also needs to be addressed. Only by solving these problems, we will come closer to building a legal State, in which the rights and freedoms of the human are actually the main direction of its functioning.

The State should recognize the human as the highest social value, legalize, legitimize, protect, protect his rights and freedoms, guarantee their real implementation. It should create for him all the necessary conditions for decent work, to provide social assistance to those who are in difficult circumstances.

\section{Bibliographic References}

ALEKSEEV, Serhii Serhiiovych. 1999. Law: The alphabet - theory - philosophy: The experience of complex research. Publishing house «Charter» No. 43. Moscow, Russian.

BODNAR, Svitlana, MIRKOVICH, Inna; KOVAL, Viktor. 2019. "Human capital development in Ukrainian education system by means of language integrated teaching" In: Dilemas contemporaneos-educacion política y valores. No. 7 (SI), pp. 14-29.

BORYCHENKO, Kateryna; HUDZ, Anna; KOVAL, Viktor ; GOLUBKOVA, Iryna; MAZUR, Anatoliy. 2019. "European standards for social protection of internally displaced persons" In: Dilemas contemporaneos-educacion política y valores. No. 7 (SI), pp. 88.

BUKANOV, Hryhoriy; KOLESNYK, Alla; TASHKINOVA, Oksana; KOTLUBAI, Viacheslav; KOVAL, Viktor. 2019. "Social marketing in public administration of social service institutions" In: Revista Genero \& Direito. No. 8, Vol. 6, pp. 457-468.

CHERMNYKH, Viktor; ZUBKO, Tatiana. 2016. "Human rights in Ukraine" In: New policy. No.1, Vol. 13, pp. 44-60.

HORNSBY V, Greece. 1997. Judgement, European Court of Human Rights, §40-45, no. 18357/91, March19. Available online. In: http://hudoc. echr.coe.int/eng?i=001-58020. Date of consultation:10/11/2019.

HUMAN RIGHTS COMMITTEE. 2001. General Comment 29, States of Emergency (article 4) of 31 August 2001, U.N. Doc. CCPR/C/21/ Rev.1/Add.11 (2001) Available online. In: http://www.unhchr.ch/ 
tbs/doc.nsf/898586b1dc7b4043c1256a450044f331/71eba4be3974b 4f7c 1256ae200517361/\$FILE/G0144470.pdf. Date of consultation: 19/10/2019.

KOSTETSKA, Kateryna; KHUMAROVA, Nina; UMANSKA, Yuliia; SHMYGOL, Nadiia; KOVAL, Viktor. 2020. "Institutional qualities of inclusive environmental management in sustainable economic development" In: Management Systems in Production Engineering. No. 28, Vol. 2, pp. 1522.

KVITKA, Sergiy; STARUSHENKO, Galina; KOVAL, Viktor; DEFORZH, Hanna; PROKOPENKO, Olha. 2019. „Marketing of Ukrainian higher educational institutions representation based on modeling of Webometrics Ranking" In: Marketing and Management of Innovations. No. 3, pp. 60-72.

LEHEZA, Yevhen; SAVIELIEVA, Maryna; DZHAFAROVA, Olena. 2018. "Structural and legal analysis of scientific activity regulation in developed countries" In: Baltic Journal of Economic Studies. No. 4, Vol. 3, pp. 147157 .

LOIZIDOU V, Turkey. 1996 Judgement, European Court of Human Rights, §45, no. 15318/89, 18 December. Available online. In: http://hudoc.echr.coe. int/eng?i=001-58007. Date of consultation: 08/08/2019.

MARTYNYUK, Anatoliy. 2014. "Modern mechanisms of state regulation of innovation activity. Naukovyy visnyk MHU. Seriya: Ekonomika ta menedzhment” In: Scientific Bulletin of Moscow State University. Series: Economics and Management. No. 7, pp. 103-107.

RABINOVYCH, Petro Moiseiovych. 2017. "Moral damage and the right to its compensation: a general theoretical approach" In: Law of Ukraine. No. 4, pp. 29-50.

SELEJAN-GUTAN, Bianca. 2011. Protectia europeana a drepturilor omului. Ed. a 4-a, rev. Bucuresti: Editura CH Beck.

SHEMSHUCHENKO, Yurii. 2017. "Constitution of Ukraine and human rights" In: Law of Ukraine. No. 8, pp. 13-16.

SHMYGOL, Nadiia; GALTSOVA, Olga; SOLOVYOV, Oleksiy; KOVAL, Viktor; ARSAWAN, I Wayan Edi. 2020. "Analysis of country's competitiveness factors based on inter-state rating comparisons" In: E3S Web Conferences, 153, 03001.

SOKOLENKO, Olha. 2019. "Administrative and legal basis of protecting citizens' rights in Ukraine” In: Actual problems of legal jurisprudence. SI, pp. 105-107. 
Yevhen Leheza, Tatiana Filipenko, Olha Sokolenko, Valerii Darahan y Oleksii Kucherenko Ensuring Human Rights in Ukraine: Problematic Issues and Ways of their Solution in the Social and Legal Sphere

THE LEGISLATION OF UKRAINE. 1991. On the rehabilitation of victims of political repression Retrieved from. Available online. In: https://zakon. rada.gov.ua/laws/show/962-12. Date of consultation: 12/03/2019.

THE LEGISLATION OF UKRAINE. 1996. Constitution of Ukraine. Retrieved from. Available online. In: https://zakon.rada.gov.ua/rada/anot/ en/254\%Do\%BA/96-\%Do\%B2\%D1\%8o. Date of consultation: 14/02/2020.

THE LEGISLATION OF UKRAINE. 1997. On Ratification of the Convention for the Protection of Human Rights and Fundamental Freedoms of 1950, the First Protocol and Protocols 2, 4, 7 and 11 to the Convention. Available online. In: https://zakon.rada.gov.ua/laws/show/475/97\%Do\%B2\%D1\%80. Date of consultation: 14/02/2020.

THE LEGISLATION OF UKRAINE. 1998. On the Commissioner of the Verkhovna Rada for human rights. Available online. In: https:// zakon.rada.gov.ua/laws/show/776/97-\%Do\%B2\%D1\%8o. Date of consultation: 22/12/2019.

THE LEGISLATION OF UKRAINE. 2001. On Citizenship in Ukraine. Available online. In: https://https://zakon.rada.gov.ua/laws/show/2235-14. Date of consultation: 11/11/2019.

THE LEGISLATION OF UKRAINE. 2001. On Immigration. Available online. In: https://zakon.rada.gov.ua/laws/show/2491-14. Date of consultation: 11/11/2019.

THE LEGISLATION OF UKRAINE. 2002. On Ukraine's accession to the UN Convention on the Status of Refugees and the Protocol on the Status of Refugees. Available online. In: https://zakon4.rada.gov.ua/laws/ show/995_363?lang=en. Date of consultation: 11/11/2019.

UKRAINE HUMAN RIGHTS MONITORING IN JANUARY. 2018-2019. Available online. Available online. In: https://forbiddentoforbid.org. ua/en/ukraine-human-rights-monitoring-in-january-2018-april-2019/. Date of consultation: 22/02/2020. 

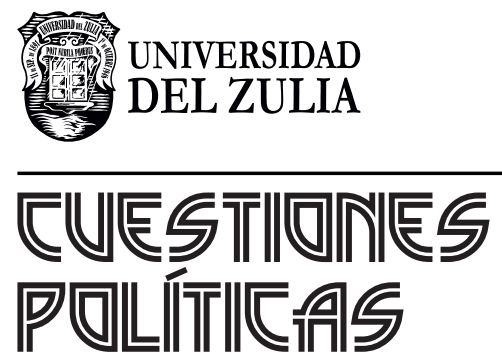

Vol. $37 \mathrm{~N}^{\circ} 64$

Esta revista fue editada en formato digital y publicada en junio de 2020, por el Fondo Editorial Serbiluz, Universidad del Zulia. Maracaibo-Venezuela 